\title{
Therapy of Myeloma In Vivo Using Marine Phospholipid in Combination with Agaricus blazei Murill as an Immune Respond Activator
}

\author{
Kentaro Murakawa1 ${ }^{1}$, Kenji Fukunaga², Masatoshi Tanouchi ${ }^{3}$ Masashi Hosokawa', \\ Zakir Hossain ${ }^{1}$ and Koretaro Takahashi ${ }^{1 *}$ \\ ${ }^{1}$ Division of Marine Biosciences, Graduate School of Fisheries Sciences, Hokkaido University (Hakodate, Hokkaido 041-8611, JAPAN) \\ ${ }^{2}$ Faculty of Engineering, Kansai University (Suita, Osaka 564-8680, JAPAN) \\ ${ }^{3}$ Cosmo Food Ltd. (Tokyo Nihonbashi 103-0001, JAPAN)
}

\begin{abstract}
Mushroom (Agaricus blazei Murill) extract has been reported to possess antitumor effects through immune activation. Here, we investigated the beneficial effects of combining A. blazei extract with marine phospholipids in comparison to $A$. blazei extract alone on myeloma sp2 tumor suppression when orally administrated. The experimental groups designed for $\mathrm{sp2}$ tumor bearing BALB/c nu/nu mice were drinks of: (1)control; (2)1.0 mg/mL squid phospholipid liposome alone; (3)0.5 mg/mL A. blazei Murill water extract alone; (4) $1.0 \mathrm{mg} / \mathrm{mL}$ squid phospholipid liposome with $0.5 \mathrm{mg} / \mathrm{mL}$ A. blazei Murill water extract in the form of those simple mixture; and $(5) 1.0 \mathrm{mg} / \mathrm{mL}$ squid phospholipid liposome with 0.5 $\mathrm{mg} / \mathrm{mL} \mathrm{A}$. blazei Murill water extract partially encapsulated. Orally administrated volumes amounted to approximately $5 \mathrm{~mL}$ per day per mouse for all groups. A. blazei Murill water extract alone and squid phospholipid alone served groups show moderate tumor suppression with total administrations of approximately $105 \mathrm{mg} / \mathrm{mouse}$ for squid phospholipid through out the experimental term. When both $A$. blazei Murill water extract and squid phospholipid were administrated simultaneously in a simple mixture form, promotional effect on cancer tumor suppression was observed. And when A. blazei Murill water extract was partially encapsulated in the squid phospholipid liposomes with total administrations being $105 \mathrm{mg} / \mathrm{mouse}$ for squid phospholipid, effect on cancer tumor suppression was more pronounced. Though there was no statistically significant difference in tumor sizes between the simple mixture form administrated group i.e. group (4) and the partially encapsulated form administrated group i.e. group (5), the tumor vanished mouse was seen in the partially encapsulated form administrated group. Thus it was concluded that combinational administration of the $A$. blazei Murill water extract and the marine phospholipid may be useful in myeloma sp2 therapy.
\end{abstract}

Key words: Agaricus blazei, marine phospholipid, myeloma

\section{INTRODUCTION}

Mushrooms have been used as an important nutritional food and therapeutic item throughout the world since ancient periods because of their special fragrance and texture $^{1-3)}$. Biochemically the protein, carbohydrate, lipid, enzyme, mineral and vitamin contents are high in mushroom and thus they have significant medical value ${ }^{4)}$. Medicinal mushrooms have always dominated in the Far East and are now increasing entering the Western marketplace because of their superior organoleptic properties as well as their recognition as true functional foods, or those recognized to have health-promoting qualities ${ }^{5}$. Mushrooms extracts are common sources of immunological, hypocholesterlemic, antiviral, antibacterial, anti-carcinogenic, anti-inflammatory and antiparasitic activities. Moreover, these mushrooms are used to combat osteoporsis, gastric ulcer, physical and emotional stress, to stimulate immunity, to improve life quality of diabetics, and to act as an effec-

* Correspondence to: Koretaro Takahashi, Division of Marine Biosciences, Graduate School of Fisheries Sciences, Hokkaido University, 31-1, Minato-cho, Hakodate, Hokkaido 041-8611, JAPAN

E-mail: kore@fish.hokudai.ac.jp

Accepted November 10, 2006 (received for review September 13, 2006)

Journal of Oleo Science ISSN 1345-8957 print / ISSN 1347-3352 online

http://jos.jstage.jst.go.jp/en/ 


\section{K. Murakawa, K. Fukunaga, M. Tanouchi et al.}

tive antioxidant ${ }^{6-9)}$.

There are many reports on mushrooms containing more than one polysaccharide with antitumor activity ${ }^{10}$. An interesting example is Agaricus blazei Murill. A. blazei is an edible mushroom, native to Brazil and presently cultivated in other areas, including Japan, Korea, China, Indonesia. It has recently received attention in folk medicine due to its use in the treatment of different ailments. A. blazei is considered as a health food in many countries after it was reported to be a source of antitumor and immunoactive compounds ${ }^{11-14}$. The water extract of $A$. blazei has potent antitumor activity in tumor-bearing mice ${ }^{15,16)}$. Protein-bound polysaccharides isolated from fruiting bodies of the A. blazei have also shown anti-tumor activity in tumor-bearing mice through activation of specific and non-specific immune response ${ }^{17-19)}$. A. blazei extract, mainly glucan has selective tumoricidal activity mediated via natural killer (NK) cell activation and promote health ${ }^{10,15,20)}$. Most of studies had taken the approach of isolating pharmaceutically active mushroom compounds. The polysaccharides from A. blazei have cytotoxic action on tumor cells through immunomodulatory activities. From the water extract(s) of $A$. blazei, a protein- $(1,6) \beta$-D-glucan complex which contained $50.2 \%$ carbohydrate and $43.3 \%$ protein, was isolated ${ }^{21}$. This protein-polysaccharide complex was characterized by growth inhibition of sarcoma180 implanted in mice and by developing immunomodulatory properties ${ }^{22,23)}$, possibly due to immunological mechanisms involving the action of various immunocompetent cells ${ }^{13,24}$. Furthermore, a highly branched (1, 3)- $\beta$-glucan segment forms the active center of the antitumor activity ${ }^{25}$. Thus, $\beta$-(1, 6)-glucan with $\beta$-(1, 3)-branched chains have exhibited strong anticancer activity by increasing immune-competent cell activity ${ }^{26}$. There are a few reports on liposomized glucan-treatment. For example, co-administration of liposomized glucan and praziquantel efficacy (\%) was significantly higher than after treatment with either compound alone, particularly in the Mesocestoides vogae infected peritoneal cavity to the liver ${ }^{27}$. It is anticipated that encapsulating anticancer glucans with $\mathrm{n}-3$ polyunsaturated fatty acid (PUFA) inserted marine phospholipids in the form of liposomes might promote the anticancer effect of glucans. Therefore, in this study, we investigated the effects of glucans from A. blazei encapsulated with n-3 polyunsaturated marine phospholipid liposomes and unencapsulated glucans on myeloma sp2 cell induced cancer in mice.

\section{EXPERIMENTAL}

\subsection{Materials}

Caco-2 (HTP-37, American Type Culture Collection) cell was obtained from Dainippon Seiyaku Co. Ltd. Raji cell was a generous gift from Institute of Development, Aging and Cancer, Tohoku University, Sendai, Japan. Minimum essential medium (MEM), Dulbecco's modified eagle medium (DMEM), Roswell park memorial institute (RPMI) 1640 medium and penicillin streptomycin were obtained from GIBCO (Grand Island, NY, USA). Fetal bovine serum (FBS), fetal calf serum (FCS) and L-glutamine were obtained from ICN Biomedicals Inc. (Costa Mesa, CA, USA). Morpholinoethanesulfonic acid (MES) was provided by Sigma Chemicals Company (St. Louis, MO, USA). Lucifer yellow $\mathrm{CH}$ Iithium salt was purchased from Molecular Probe Inc. (Eugene, OR, USA). 2-[4-(2-Hydroxyethyl)-1-piperazinyl] ethanesulfonic acid (HEPES) was obtained from Dojindo Laboratories (Kumamoto, Japan). Phospholipase D (PLD) from Streptomyces sp. was a generous gift from Asahi Chemical Industry Co. (Fuji, Japan). L-Serine was purchased from Wako Pure Chemical Industries Ltd. (Osaka, Japan). Squid meal phospholipids were generous gifts from Nippon Chemical and Feed Co. Ltd., (Hakodate, Hokkaido, Japan).

\subsection{Cell culture}

Caco-2 cells were grown in MEM with $26.2 \mathrm{mM}$ sodium bicarbonate, $100 \mathrm{IU} / \mathrm{mL}$ penicillin, $100 \mu \mathrm{g} / \mathrm{mL}$ streptomycin, $1 \%$ non-essential amino acids, and $10 \%$ heat-incubated $\mathrm{FBS}$ in a $95 \%$ air- $5 \% \mathrm{CO}_{2}$ atmosphere at $37^{\circ} \mathrm{C}$. Raji cells were grown in RPMI 1640 medium supplemented with $10 \%$ heat-incubated FBS in the same incubator. The cells were grown in $25-\mathrm{cm}^{2}$ flasks, and subcultured at fourday intervals at a concentration of $5 \times 10^{4}$ cells $/ \mathrm{mL}$.

\subsection{Separation of PC from squid meal phospholipids}

Phosphatidylcholine (PC) was separated from squid meal phospholipid following our previous method ${ }^{28}$. Just in brief, the phospholipid from squid meal was applied to a silica gel chromatography column and eluted with chloroformmethanol to afford PC. PC was monitored on thin layer chromatography (TLC) by spraying with Dragendorff reagent and by comparing with an authentic PC standard.

\subsection{Conversion of PC to PS via transphosphatidylation}

Phosphatidylserine (PS) was obtained from squid meal $\mathrm{PC}$ via PLD-mediated transphosphatidylation as described by Hosokawa et al..$^{29)}$. Briefly, PC was dissolved in $2.5 \mathrm{~mL}$ of ethyl acetate and then $3.0 \mathrm{~mL}$ of $0.2 \mathrm{M}$ acetate buffer $(\mathrm{pH}$ 5.5) containing certain amounts of $\mathrm{PLD}, \mathrm{CaCl}_{2}$, albumin and $\mathrm{L}$-serine was added. The mixture was incubated at $30^{\circ} \mathrm{C}$ for $24 \mathrm{~h}$ with $500 \mathrm{rpm}$ stirring. After the reaction, the solution was mixed with chloroform/methanol/water (6/3/1.3), and the chloroform layer was collected. It was evaporated and loaded on TLC plates to obtain the PS.

\subsection{Fatty acid profile of squid meal PC and PS}

Individual methyl esters were derived from the PC or PS 
samples following the method of Lepage and $\mathrm{Roy}^{30)}$ with slight modification. The dried samples were dissolved in $5 \%$ methanolic- $\mathrm{HCl}$. The mixture was shaken, kept at $80^{\circ} \mathrm{C}$ for $2 \mathrm{~h}$ and then $2 \mathrm{~mL}$ water and $3 \mathrm{~mL}$ hexane were added. The hexane layer was collected, concentrated and subjected to gas chromatographic analysis with a $0.5 \mu \mathrm{m}$ PEG- $^{-}$ $20 \mathrm{M}$ liquid phase-coated $40 \mathrm{~m} \times 1.2 \mathrm{~mm}$ diameter G-300 column (Chemicals Evaluation and Research Institute, Saitama, Japan) connected to a Hitachi 163 gas chromatograph (Hitachi Co. Ltd., Ibaraki, Japan) that was equipped with flame ionization detector. The temperatures of the column, detector and injection port were 170, 240 and $250^{\circ} \mathrm{C}$, respectively. The fatty acids were identified by comparing the peak relative retention times with authentic standards (St. Louis, MO, USA) following the method of Takahashi et $a l^{311}$.

\subsection{Extraction of water-soluble immunomodulatory activa- tor from A. blazei}

The powder from dehydrated and milled mushrooms $(25$ g) was suspended in $200 \mathrm{~mL}$ distilled water. Then left for 5 $\mathrm{h}$ at room temperature with $200 \mathrm{rpm}$ stirring. The suspensions were centrifuged at $5000 \mathrm{rpm}$ for $30 \mathrm{~min}$ and light orange color extracts were obtained. The supernatant was freeze dried. And this A. blazei Murill water extract was stored at $-50^{\circ} \mathrm{C}$ until use.

\subsection{Transportation of lucifer yellow}

To confirm whether the intestinal epithelial monolayer is formed or not, transport of lucifer yellow was measured. This experiment was performed following our previous paper ${ }^{32}$. Briefly, Caco-2 cells were plated at a density of $2 \times 10^{5}$ cells $/ \mathrm{cm}^{2}$ onto a $12 \mathrm{~mm}$ polycarbonate transwell filter with $0.4-\mu \mathrm{m}$ pores and a surface area of $0.6 \mathrm{~cm}^{2}$ (Millipore Corporation Ltd., Bedford, MA, USA). Before each experiment, cells were washed three times with PBS and pre-equilibrated for $30 \mathrm{~min}$ in Hanks balanced salt solution (HBSS) containing $10 \mathrm{mM} \mathrm{MES} \mathrm{at} \mathrm{pH} 6.0$ in the apical (AP) chamber and HBSS containing $10 \mathrm{mM}$ HEPES at $\mathrm{pH} 7.4$ in the basolateral (BL) chamber. $0.5 \mathrm{mM}$ Lucifer yellow (LY) HBSS solution ( $\mathrm{pH}$ 6.0) was applied on the Caco-2 cell monolayer in the AP chamber. After incubation at $37^{\circ} \mathrm{C}$ for $2 \mathrm{~h}$, the HBSS in the BL chamber was collected, and the concentration of LY was determined by measuring the fluorescent intensity with a Hitachi F-2000 fluorescence spectrophotometer (Hitachi Co. Ltd., Ibaraki, Japan). The excitation and emission wavelengths used were 430 and 540 $\mathrm{nm}$, respectively.

\subsection{Liposome preparation}

Liposomes were prepared by a lipid film hydration method $^{33)}$ from a lipid mixture film containing PC, PS and cholesterol in a molar ratio of 1:1:2. The lipid film was then hydrated with water or with Agaricus blazei Murrill water extract to exfoliate phospholipid bilayers by vigorous vortex mixing for $5 \mathrm{~min}$. The liposomes thus formed were extruded 5 times through two stacked polycarbonate membrane filter (Whatman Inc. Newton, MA, USA) with a pore size of $400 \mathrm{~nm}$. The particle size distribution in the sample was analyzed by dynamic light scattering using a particle size analyzer LB-500 (HORIBA, Japan).

\subsection{Liposome stability in digestive track model}

Liposomes were prepared in $150 \mathrm{mM}$ calcein solution (10 $\mathrm{mM}$ Tris- $\mathrm{HCl}, 145 \mathrm{mM} \mathrm{NaCl}, \mathrm{pH}$ 7.4). Then it was ultra centrifuged twice to remove the unencapsulated calcein. The liposome solution thus prepared was dispersed into $10 \mathrm{mM}$ Tris- $\mathrm{HCl}$ buffer to make the liposome concentration 10 $\mu \mathrm{mol} / \mathrm{mL}$. Stability evaluation of the liposomes in the digestive juice model was done as follows; One hundred $\mu \mathrm{L}$ of the liposome solution was added to $1.9 \mathrm{~mL}$ of each digestive juice model and incubated for an hour at $37^{\circ} \mathrm{C}$. Digestive juice models employed were $10 \mathrm{mM}$ Tris- $\mathrm{HCl}(145 \mathrm{mM}$ $\mathrm{NaCl}, \mathrm{pH} 7.4$ ), same buffer with $\mathrm{pH} 2.0,10 \%$ bovine bile in PBS, pH 7.2, 2.8\% pancreatin solution in PBS pH 7.2. To the $0.5 \mathrm{~mL}$ of Tris- $\mathrm{HCl}$ buffer ( $145 \mathrm{mM} \mathrm{NaCl}, \mathrm{pH} 2.0)$ solution, same volume of Tris- $\mathrm{HCl}$ buffer $(145 \mathrm{mM} \mathrm{NaCl}, \mathrm{pH} 9.5)$ was added, then ultra centrifuged at $95000 \times \mathrm{g}, 10 \mathrm{~min}\left(4^{\circ} \mathrm{C}\right)$ in order to remove the leaked calcein in the digestive juice model. As for the bovine bile solution and pancreatin model, ultrafilteration (Millipore, Ultrafree-CL, $0.1 \mu \mathrm{m}$ ) at $3,300 \times \mathrm{g}$ for $30 \mathrm{~min}\left(4^{\circ} \mathrm{C}\right)$ was carried out to recover the leaked calcein. The excitation and emission wavelengths used for the calcein amount determination were 490 and $520 \mathrm{~nm}$, respectively.

\subsection{Trapping efficiency}

Calcein was entrapped into liposomes by preparing liposome in $0.1 \mathrm{mM}$ calcein solution (10mM Tris- $\mathrm{HCl}, 145 \mathrm{mM}$ $\mathrm{NaCl}, \mathrm{pH}$ 7.4). Then $40 \mu \mathrm{L}$ of this liposome suspension was added to $2.0 \mathrm{~mL}$ of $10 \mathrm{mM}$ Tris- $\mathrm{HCl}$ buffer. Fluorescent intensity at excitation and emission wavelengths of 490 and $520 \mathrm{~nm}$, respectively, using a Hitachi F-2000 fluorescence spectrophotometer was measured (Ft). By adding 10 $\mathrm{mM}$ cobalt chloride solution for $20 \mu \mathrm{L}$ uncapsulated calcein was quenched to give the fluorescent intensity only from the encapsulated calcein (Fin). Finally, by adding 20\% Triton $\times-100$ for $20 \mu \mathrm{L}$, all the calcein was quenched by exposing the encapsulated calcein to $\mathrm{Co}^{2+}(\mathrm{Fq})$. Trapping efficiency was calculated as follows.

Trapping efficiency $(\%)=$

$$
(\mathrm{Fin}-\mathrm{Fq} \times \mathrm{r}) /(\mathrm{Ft}-\mathrm{Fq} \times \mathrm{r}) \times 100
$$

Where $r$ is a volume correction factor

\subsection{TER measurement}

The transepithelial electrical resistance (TER) was measured using a Millicell ${ }^{(R)}$ ERS (Millipore Co., Bedford, MA, USA), to ensure the integrity of the monolayers formed on 
the filter. TER measurements were started during the preequilibration time in HBSS and continued during the treatment. Values were recorded every 30 min over the experimental period. Control filters were maintained with only HBSS for $3 \mathrm{~h}$ experiments. TER data was expressed as relative TER values against initial.

\subsection{Confirmation of differentiation of Caco-2 cells into M- cells}

Caco-2 cells were grown on polycarbonate transwell filter as described before ${ }^{32}$. Raji cells in RPMI: DMEM 1:2 $\left(8.3 \times 10^{4}\right.$ cells $\left./ \mathrm{mL}\right)$ were added to the basolateral chamber then cocultured for 4-6 days. If some of the Caco- 2 cells have differentiated into M-cells by a soluble induction factor secreted from Raji cells, the alkaline phosphatase activity should decline. Alkaline phosphatase activity was visualized by use of ELF 97 endogenous phosphatase detection kit (Molecular Probes Inc., Eugene, USA) on a slide glass with cell monolayer on it. Namely, the cell monolayer was fixed with PBS containing $10 \%$ formalin $(\mathrm{pH} \mathrm{7.4)}$ ) and then washed three times with PBS. The cells were dipped into PBS containing $0.2 \%$ Tween 20 ( $\mathrm{pH} 7.4$ ) for $10 \mathrm{~min}$ and then rinsed with PBS for more than $10 \mathrm{~min}$. The cell monolayer filter were carefully taken out and transferred to a slide glass. Reaction itself was terminated with PBS ( $\mathrm{pH}$ 8.0) containing $25 \mathrm{mM}$ EDTA and $5 \mathrm{mM}$ L-phenylalanine.

Another index employed to confirm the differentiation into M-cells was checking latex beads import. The Caco-2 cell monolayers were incubated for 30 min with $2 \%$ FCS containing HBSS. HBSS ( $2 \%$ FCS) was added to fluorescent latex bead. Then after $30 \mathrm{~min}$, it was centrifuged at $3000 \times \mathrm{g}$ and the supernatant was removed. Lump was separated into individual particles while rinsing with a sonicator. This rinsing was repeated for several times. Finally, the fluorescent intensity of the recovered HBSS from the basolateral chamber was measured. The excitation and emission wavelengths used were 365 and $415 \mathrm{~nm}$, respectively. Number of the latex beads was counted from a calibration curve showing the relationship between the fluorescent intensity and the number of the beads.

\subsection{Transport of $\beta$-glucan encapsulated liposomes}

Caco-2 and Raji cells were washed three times with HBSS containing $2 \% \mathrm{FCS}$. It was incubated at $4^{\circ} \mathrm{C}$ or $37^{\circ} \mathrm{C}$ for 30 min with $400 \mu \mathrm{L}$ and $600 \mu \mathrm{L}$ HBSS containing $2 \%$ FCS in apical and basolateral chamber, respectively. Then, it was taken in new plate inserts and incubated at $4^{\circ} \mathrm{C}$ or $37^{\circ} \mathrm{C}$ for 30 min with $400 \mu \mathrm{L}$ and $600 \mu \mathrm{L}$ HBSS containing $2 \%$ FCS in apical and basolateral chamber, respectively. Transportation of $\beta$-glucan encapsulated liposomes from apical to basolateral chamber was determined by limulus test using Endospect ${ }^{\circledR}$ ES-50M Set (Seikaguku Corporation, Tokyo, Japan).

\subsection{Animal study design}

Six-week-old male BALB/c nu/nu mice were purchased from Hokudo Ltd. (Abuta, Hokkaido, Japan). Sp-2 myeloma $\left(1.5 \times 10^{5}\right.$ cells/mouse) was inoculated subcutaneously. Mice were acclimatized for 1 week. All animals were provided free access to drinking. Weanling BALB/c mice were divided into five groups. After 20 days of myeloma sp2 cell inoculation into mice, liposomal drinks were orally administered for 3 weeks. Mice were provided with drinks containing $1.0 \mathrm{mg} / \mathrm{mL}$ squid phospholipid liposome alone, 0.5 $\mathrm{mg} / \mathrm{mL}$ A. blazei water extract alone, $1.0 \mathrm{mg} / \mathrm{mL}$ squid phospholipid liposome with $0.5 \mathrm{mg} / \mathrm{mL}$ A. blazei water extract mixture, and $1.0 \mathrm{mg} / \mathrm{mL}$ squid phospholipid liposome with $0.5 \mathrm{mg} / \mathrm{mL}$ A. blazei water extract partially encapsulated in groups II, III, IV and V, respectively. A control (group I) was also maintained. The orally administered liposomal drink amount per mouse was approximately $5 \mathrm{~mL}$ per day for all groups.

\subsection{Tumor size}

After 20 days of myeloma sp2 cell implantation, tumors were formed. The tumor size was determined through direct measurement with calipers. After 3 weeks of drinks serving, the mice were sacrificed, and the tumors were carefully removed and weighed.

\subsection{Statistical analysis}

Statistical analysis for comparison between two groups was performed using student's $t$-test. Data was expressed as means \pm standard deviations (SD). A difference was considered significant at $P$. The resulting $P$ values for each group are indicated in the figures.

\section{RESULTS}

\subsection{Fatty acid profile analyses}

Fatty acid profiles of squid meal PC and PS are shown in Table 1. The major fatty acids were 16:0, and 22:6 in squid meal PC, then 20:5. There was no change in fatty acid profile during transphosphatidylation.

\subsection{Liposome size distribution}

The mean particle sizes of freeze-thawed liposomes of $\mathrm{PC} / \mathrm{PS} / \mathrm{Chol}=1: 1: 2$ ranged from 46.2 to $560,65.8$ to 504 and 129 to $1102 \mathrm{~nm}$, respectively for 0,4 and 5 times freezethawing, respectively (Fig. 1).

\subsection{Stability of liposomes}

As shown in Table 2, incubation at $\mathrm{pH} 2.0$ Tris- $\mathrm{HCl}$ solution containing $145 \mathrm{mM} \mathrm{NaCl}$ caused the release of $4.2 \pm$ $0.2 \%$ and $11.7 \pm 4.4 \%$ of entrapped calcein from liposomes composed of PC and PC/PS/Chol (1: 1: 2 molar ratio), respectively. Treatment with $10 \%$ bovine bile acid resulted 
Table 1 Fatty Acid Composition of Squid Meal Phospholipid.

\begin{tabular}{lrc}
\hline & \multicolumn{2}{c}{$\%$} \\
\cline { 2 - 3 } \multicolumn{1}{c}{ Fatty acid } & Squid PC & Transphosphatidylated PS \\
\hline $\mathrm{C}_{16: 0}$ & 36.3 & 37.2 \\
$\mathrm{C}_{16: 1}$ & 1.3 & 1.8 \\
$\mathrm{C}_{18: 1}$ & 3.6 & 3.1 \\
$\mathrm{C}_{18: 2}$ & $\operatorname{tr}$ & $\operatorname{tr}$ \\
$\mathrm{C}_{20: 1}$ & $\operatorname{tr}$ & $\operatorname{tr}$ \\
$\mathrm{C}_{22: 1}$ & $\operatorname{tr}$ & $\operatorname{tr}$ \\
$\mathrm{C}_{20: 4}$ & $\operatorname{tr}$ & $\operatorname{tr}$ \\
$\mathrm{C}_{20: 5}$ & 9.1 & 8.5 \\
$\mathrm{C}_{22: 6}$ & 42.2 & 40.1 \\
Others & 7.5 & 9.3 \\
\hline
\end{tabular}

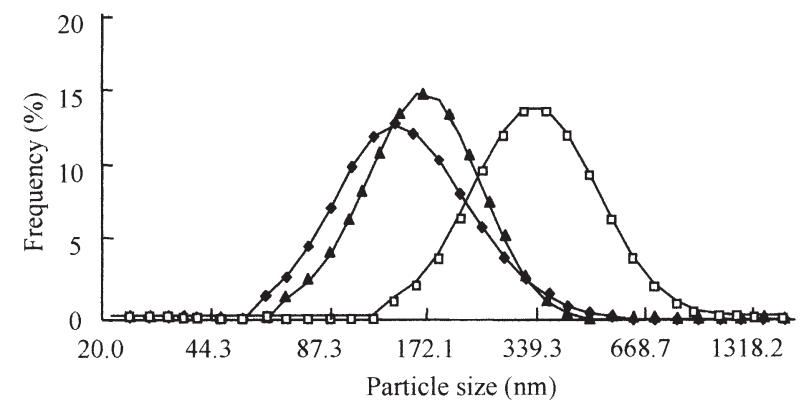

Fig. 1 Particle Size Distribution of Freeze-thawed Liposomes. Lipid composition of liposomes was PC:PS:Chol=1:1:2. The size distribution of liposomes was analyzed by dynamic light scattering using a particle size analyzer.

Number of Extrusions through membrane: $\diamond, 0$ times; $\boldsymbol{\Delta}$, 4 times; $\square, 5$ times

Table 2 Stability of Liposomes In Vitro.

\begin{tabular}{|c|c|c|c|c|}
\hline \multirow{2}{*}{$\begin{array}{l}\text { Lipid } \\
\text { composition of } \\
\text { liposomes } \\
\text { (molar ratio) }\end{array}$} & \multicolumn{4}{|c|}{ Leakage of calcein $(\%)$} \\
\hline & $\mathrm{pH} 7.4$ & $\mathrm{pH} 2.0$ & $\begin{array}{l}10 \% \text { bile } \\
\text { acid }\end{array}$ & $\begin{array}{l}2.8 \% \\
\text { pancreatin }\end{array}$ \\
\hline $\mathrm{PC}$ & $1.5 \pm 3.7$ & $4.2 \pm 0.2$ & $90.8 \pm 19.1$ & $45.7 \pm 3.4$ \\
\hline PC/Chol (7:2) & $3.2 \pm 0.2$ & $1.2 \pm 1.4$ & $33.9 \pm 7.9$ & $52.9 \pm 2.2$ \\
\hline $\begin{array}{l}\mathrm{PC} / \mathrm{PS} / \mathrm{Chol} \\
(7: 3: 2)\end{array}$ & $0.1 \pm 0.1$ & $0.6 \pm 0.3$ & $58.8 \pm 6.2$ & $45.2 \pm 1.6$ \\
\hline$(1: 1: 2)$ & $5.5 \pm 1.4$ & $11.7 \pm 4.4$ & $13.1 \pm 1.1$ & $29.6 \pm 1.8$ \\
\hline
\end{tabular}

in $90.8 \pm 19.1,33.9 \pm 7.9,58.8 \pm 6.2$ and $13.1 \pm 1.1 \%$ leakage of calcein from liposomes composed of PC, PC/Chol (7: 2 molar ratio), $\mathrm{PC} / \mathrm{PS} / \mathrm{Chol}$ (7: 3: 2 molar ratio), and $\mathrm{PC} / \mathrm{PS} / \mathrm{Chol}$ (1: 1: 2 molar ratio), respectively. The leakage of calcein from the liposomes composed of $\mathrm{PC}, \mathrm{PC} / \mathrm{Chol}(7$ : 2 molar ratio), $\mathrm{PC} / \mathrm{PS} / \mathrm{Chol}$ (7: 3: 2 molar ratio), and $\mathrm{PC} / \mathrm{PS} /$ Chol (1: 1: 2 molar ratio) when treated with $2.8 \%$ pancreatin were $45.7 \pm 3.4,52.9 \pm 2.2,45.2 \pm 1.6$, and $29.6 \pm$ $1.8 \%$, respectively. These results suggest that the stability of liposomes containing PC/PS/Chol (1:1:2 molar ratio) is relatively high.

\subsection{Trapping efficiency}

$\mathrm{PC} / \mathrm{PS} / \mathrm{Chol}=7: 3: 2$ and 1: 1: 2 had entrapped calcein more than $\mathrm{PC}$ alone and $\mathrm{PC} / \mathrm{Chol}$ (Fig. 2). However, the trapping efficiency remained $8 \%$ at the most.

3.5 Liposomes increased the TER of Caco-2 cell monolayer

Treated liposomes increased the TER during the experimental period (Fig. 3). Treatment of Caco-2 monolayers with PC/PS/Chol (1: 1: 2 molar ratio), PC/PS (1: 1 molar ratio) resulted in increases in the relative TER by 1.40 and 1.35 , respectively in the 180 -min treatment. The relative TER of the control experiment changed only slightly over the treatment time.

\subsection{Liposomes may decreased tight junction permeability}

The LY flux across the Caco-2 cell monolayers is shown in Fig. 4 after incubation with PC/PS/Chol (1: 1: 2 molar ratio) and PC/PS (1:1 molar ratio) liposomes. The perme-

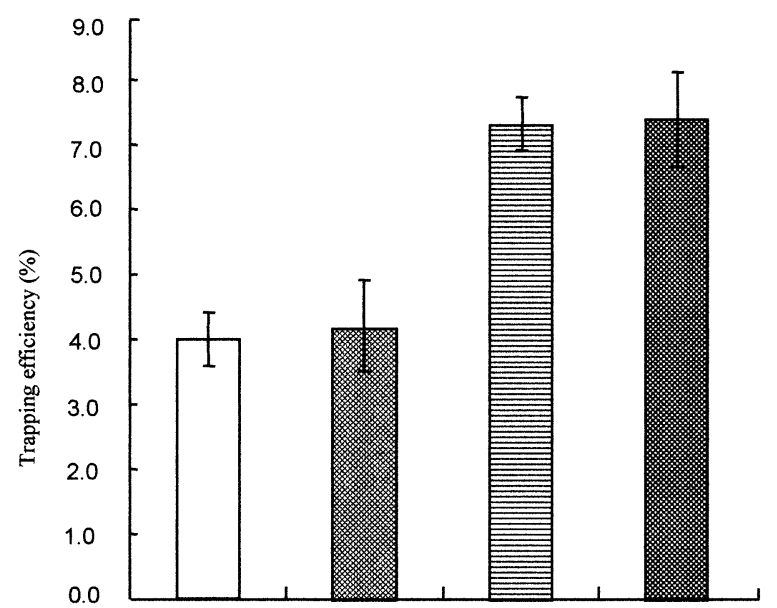

Fig. 2 Trapping Efficiency of Liposomes Prepared from PC, PC:Chol $=7: 2$, PC:PS:Chol= 7:3:2 and 1:1:2. The results are the means $\pm \mathrm{SD}(\mathrm{n}=4)$.
$\square: \mathrm{PC}$
: $\mathrm{PC} / \mathrm{Chol}=7: 2$
政: $\mathrm{PC} / \mathrm{PS} / \mathrm{Chol}=7: 3: 2$
$: \mathrm{PC} / \mathrm{PS} / \mathrm{Chol}=1: 1: 2$ 
ation of LY decreased significantly when treated with PC/PS/Chol (1: 1: 2 molar ratio) and PC/PS (1:1 molar ratio) liposomes.

\subsection{Transportation of $\beta$-glucans across the Caco- 2 cell monolayers}

The transportation of $\beta$-glucan and $\beta$-glucan-containing liposomes through the Caco-2 or cocultured (M-cell) monolayers was determined by limulus test. Transportation of $\beta$ glucans from apical to basolateral layers was 30 and 72 $\mathrm{pg} / \mathrm{mL}$ for Caco-2 and M-cell respectively. It was 62 and 56 $\mathrm{pg} / \mathrm{mL}$ when treated with $\beta$-glucans encapsulated liposomes and $\beta$-glucans and liposomes mixture on coculture monolayers. We observed a diluted milk looking solution (which is no doubt liposomes) coming out to the outer well (data not shown). But transportation increase of $\beta$-glucan across the Caco-2 monolayers was not clear for the liposome form donation. It may due to methodological error. We should increase the amount of encapsulated $\beta$-glucan to minimize the methodological error.

\subsection{Drink intake and weight gain}

The drinks were well accepted by the mice. The consumed volume of the drinks by myeloma sp2 bearing

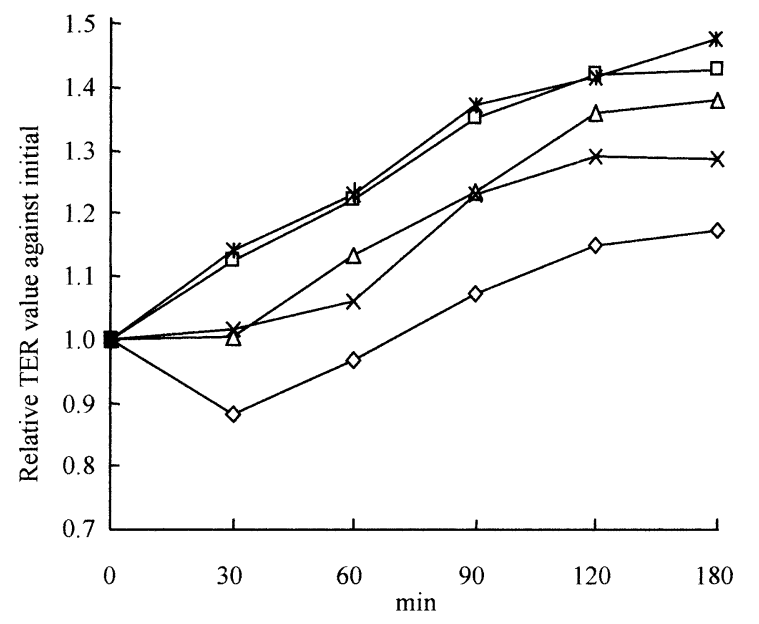

Fig. 3 Effect of Phospholipid Liposomes on TER of Caco2 Cells Grown on Filter.

Caco-2 Monolayer was treated with liposomes for $180 \mathrm{~min}$. The TER values were expressed as the relative TER value to the value at zero min at each time point.

$\diamond:$ Control

口: $1 \mathrm{mM}$ squid meal PC/PS/Chol (1:1:2) liposomes

$\Delta: 1 \mathrm{mM}$ squid meal PC/PS (1:1) liposomes

$\mathrm{x}: 1 \mathrm{mM}$ soy PC/PS/Chol (1:1:2) liposomes

* : $1 \mathrm{mM}$ soy PC/PS (1:1) liposomes
$\mathrm{BALB} / \mathrm{c}$ mice is presented in Table 3. The weight gain was measured once a week. Mean weight of body in all groups is shown in Fig 5. There was no significant difference in drinks intake, or body weight gain between mice among the different groups.

$3.9 \beta$-glucan and phospholipid inhibited the growth of myeloma sp2 tumor

To determine whether $\beta$-glucan has a direct growthinhibitory effect on myeloma sp2 cancer in vivo, myeloma sp2 cells were implanted subcutaneously into BALB/c mice. Daily oral administration of $\beta$-glucan suppressed tumor growth (Fig. 6 and 7). As shown Fig. 6 and 7, A. blazei Murill water extract alone and squid phospholipid alone served groups showed moderate tumor suppression with total administrations of approximately $105 \mathrm{mg} / \mathrm{mouse}$ through out the experiment term. When both A. blazei

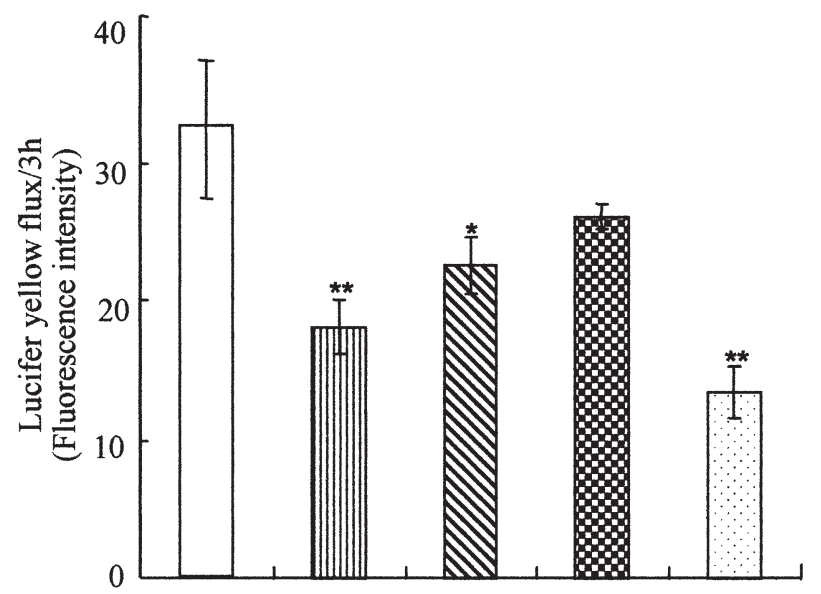

Fig. 4 Effect of Liposomes on Permeability of Lucifer Yellow Through Caco-2 Cell Monolayers.

A lucifer yellow (LY) solution (0.5 mM in HBSS) encapsulated liposome was added to the apical side, then the plate was incubated at $37^{\circ} \mathrm{C}$ for $2 \mathrm{~h}$. HBSS was collected from the basal side, and fluorescence intensity of each solution was measured with fluorescence spectrophotometer. The excitation and emission wavelengths were $430 \mathrm{~nm}$ and $540 \mathrm{~nm}$. The results are the means \pm SD $(n=4)$. Asterisks indicate significant difference as compared to control $(* P<0.05, * * P<0.01)$.

$\square:$ Control

IIIII : $1 \mathrm{mM}$ squid meal PC/PS/Chol (1:1:2) liposomes

$\mathbb{N}: 1 \mathrm{mM}$ squid meal PC/PS (1:1) liposomes

8: $1 \mathrm{mM}$ soy PC/PS/Chol (1:1:2) liposomes : $1 \mathrm{mM}$ soy PC/PS (1:1) liposomes 
Table 3 Consumed Volume of the Sample Suspension by Myeloma sp2 Bearing BALB/c Mice.

\begin{tabular}{lc}
\hline Group & $\mathrm{mL}$ \\
\hline Control & $6.8 \pm 0.6$ \\
Liposome & $7.1 \pm 0.3$ \\
Agaricus & $7.2 \pm 0.3$ \\
AaL : Agaricus and Liposome mixture & $7.4 \pm 0.3$ \\
AeL : Agaricus encapsulated Liposome & $7.4 \pm 0.3$ \\
\hline
\end{tabular}

Murill water extract and squid phospholipid were administrated simultaneously in a simple mixture form, promotional effect on cancer tumor suppression was observed. And when A. blazei Murill water extract was partially encapsulated with squid phospholipid liposome with total administrations being $105 \mathrm{mg} / \mathrm{mouse}$ for both components, promotional effect on cancer tumor suppression was more prominent. Moreover, disappearance of tumors occurred in the group administered with the partially encapsulated form.

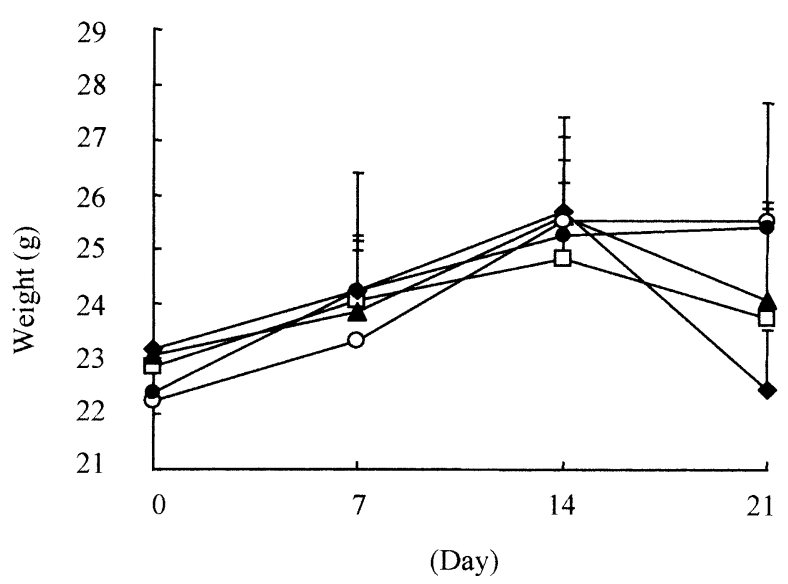

Fig. 5 Effect of Liposome and A. blazei Samples on the Body Weight of Myeloma sp2 Bearing BALB/c nu/nu Mice.

Myeloma sp2 tumor cells $\left(1.5 \times 10^{5}\right.$ cells $/$ mice $)$ were implanted into mice. Twenty days after implantation of the cells, liposomes $(1.0 \mathrm{mg} / \mathrm{mL})$, A. blazei $(0.5 \mathrm{mg} / \mathrm{mL})$, A. blazei $(0.5 \mathrm{mg} / \mathrm{mL})$ liposomes $(1.0 \mathrm{mg} / \mathrm{mL})$ mixture and A. blazei $(0.5$ $\mathrm{mg} / \mathrm{mL})$ encapsulated liposomes $(1.0 \mathrm{mg} / \mathrm{mL})$ were administered for 21 days.

$\diamond$ : Control $(\mathrm{n}=7) ; \square: 1.0 \mathrm{mg} / \mathrm{mL}$ liposomes $(\mathrm{n}=7) ; \quad \boldsymbol{\Delta}: 0.5 \mathrm{mg} / \mathrm{mL}$ A. blazei $(\mathrm{n}=7) \quad \bigcirc: 0.5$ $\mathrm{mg} / \mathrm{mL}$ A. blazei $-1.0 \mathrm{mg} / \mathrm{mL}$ liposomes mixture $(\mathrm{n}=7) \bigcirc: 0.5 \mathrm{mg} / \mathrm{mL}$ A. blazei encapsulated 1.0 $\mathrm{mg} / \mathrm{mL}$ liposomes $(\mathrm{n}=7)$

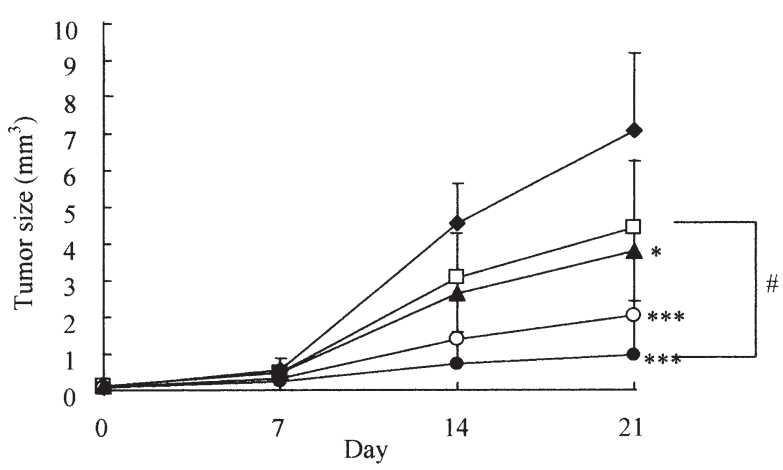

Fig. 6 Effect of Liposome and A. blazei on Tumor Sizes of Myeloma sp2 Tumors Bearing BALB/c nu/nu Mice. Myeloma sp2 tumor cells $\left(1.5 \times 10^{5}\right.$ cells $/$ mice $)$ were implanted into mice. Twenty days after implantation of the cells, liposomes $(1.0 \mathrm{mg} / \mathrm{mL})$, A. blazei $(0.5 \mathrm{mg} / \mathrm{mL})$, A. blazei $(0.5 \mathrm{mg} / \mathrm{mL})$ liposomes $(1.0 \mathrm{mg} / \mathrm{mL})$ mixture and A. blazei $(0.5$ $\mathrm{mg} / \mathrm{mL})$ encapsulated liposomes $(1.0 \mathrm{mg} / \mathrm{mL})$ were administered for 21 days. The results are the means $\pm \mathrm{SD}(\mathrm{n}=7)$. Asterisks indicate significant difference as compared to control $\left({ }^{*} P<0.05, * * * P<0.001\right)$ and liposome vs AeL $(\# P<0.05)$.

$\checkmark$ : Control $(\mathrm{n}=7) ; \quad \square: 1.0 \mathrm{mg} / \mathrm{mL}$ liposomes $(\mathrm{n}=7) ; \quad \boldsymbol{\Delta}: 0.5 \mathrm{mg} / \mathrm{mL}$ A. blazei $(\mathrm{n}=7) \quad \bigcirc: 0.5$ $\mathrm{mg} / \mathrm{mL}$ A. blazei- $1.0 \mathrm{mg} / \mathrm{mL}$ liposomes $(\mathrm{n}=7)$ $0.5 \mathrm{mg} / \mathrm{mL}$ A. blazei encapsulated $1.0 \mathrm{mg} / \mathrm{mL}$ liposomes $(\mathrm{n}=7)$

If we succeed in encapsulating larger amounts of A. blazei Murill water extract in the liposomes, there should be a significant difference in tumor sizes between groups IV and V.

\section{DISCUSSION}

Mushroom constituents may inhibit promotion or progression by exerting direct cytotoxicity against tumor cells $^{15)}$, interfering with tumor angiogenesis ${ }^{14)}$, or upregulating other nonimmune tumor-suppressive mechanisms. The whole-mushroom extracts contain compounds that may modulate tumorigenesis and carcinogenesis at different stages and/or may act at the same stage but through different mechanisms. Thus, it could potentially provide additive, or even synergistic, effects in the prevention and treatment of cancer ${ }^{34}$. In the current study, we found inhibition of myeloma in vivo with A. blazei extract only and inhibition was more efficient with A. blazei extract encapsulated with marine phospholipid liposomes.

Various polysaccharides and protein-bound polysaccha- 


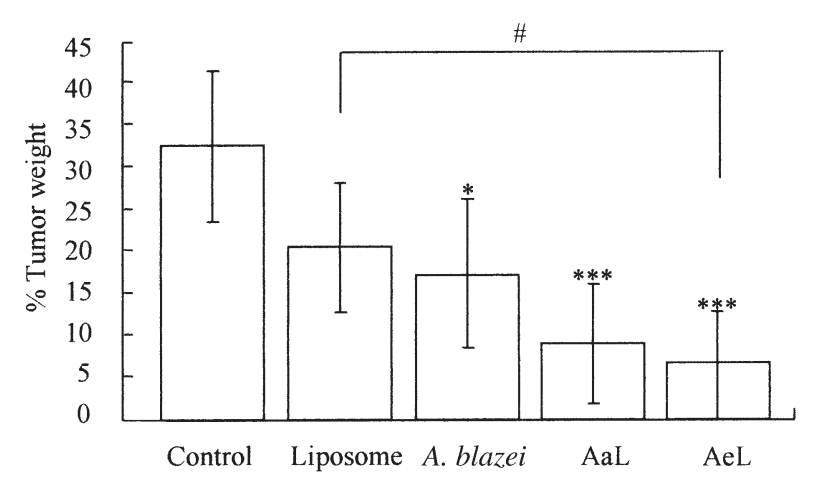

Fig. 7 Effect of Liposome and A. blazei on Tumor weight (\%) against Body Weight of Myeloma sp2 Bearing BALB/c nu/nu Mice.

Myeloma sp2 tumor cells $\left(1.5 \times 10^{5}\right.$ cells $/$ mice $)$ were implanted into mice. Twenty days after implantation of the cells, liposomes $(1.0 \mathrm{mg} / \mathrm{mL})$, A. blazei $(0.5 \mathrm{mg} / \mathrm{mL})$, AaL; A. blazei $(0.5 \mathrm{mg} / \mathrm{mL})$ liposomes $(1.0 \mathrm{mg} / \mathrm{mL})$ mixture and AeL; A. blazei $(0.5 \mathrm{mg} / \mathrm{mL})$ encapsulated liposomes $(1.0 \mathrm{mg} / \mathrm{mL})$ were administered for 21 days. The results are the means $\pm \mathrm{SD}(\mathrm{n}=7)$. Asterisks indicate significant difference as compared to control $(* P<0.05$, $* * * P<0.001)$.

rides have been isolated from the fruiting bodies of the $A$. blaze $i$ and have shown anti-tumor activity in tumor-bearing mice. These compounds appear to stimulate the host immune response by enhancement of macrophage, NK cells and cytolytic $\mathrm{T}$ lymphocytes activities, which participate in the antitumor response in the sarcoma 180 or Meth A fibrosarcoma-bearing mice systems ${ }^{19}$. Substances occurring in the powdered A. blazei meal may stimulate the hepatic detoxifying enzymatic system or the antioxidant free radical scavenging activities ${ }^{35}$. A. blazei fed in dry powdered form to Wister rats at 10\% of the diet exhibited significant chemopreventive influence on the promoting phase of the rat chemical hepatocarcinogenesis ${ }^{36}$. Similar antimutagenic effects were reported for diets containing powder of other mushroom Lentinula edodes ${ }^{37,38)}$. It was observed that the NK cell activity was maintained at a more significant level in the gynecological cancer patient groups undergoing chemotherapy when A. blaze $i$ was orally consumed. This suggests that $A$. blazei extracts might have some beneficial effects on innate immunity in gynecological cancer patients undergoing chemotherapy. NK cells display dramatic effects on the reduction of tumor growth as well as on the inhibition of metastatic tumors ${ }^{39}$. The mechanisms of controlling NK cell cytotoxicity are gradually being elucidated but still remain fragmentary. It has also been reported that direct intratumoral injection of $A$. blazei extract can induce apoptosis and cell-cycle arrests of tumor cells ${ }^{15}$. Additionally, it was found that A. blazei extract consumption reduced some chemotherapy-related side effects in cancer patients. In general insomnia, appetite, alopecia, body weight, nausia/vomiting, emotional conditions, discomfort and general body strength were all improved, indicating the A. blazei consumption could be effective to reduce some chemotherapy-associated side effects $^{40)}$. A. blazei extracted glucan encapsulated $n-3$ PUFA inserted marine phospholipid might be more useful to assist $A$. blazei extracted cancer therapy because they should decrease side effects and promote the effectiveness of cancer cell differentiation. An in vitro study shown marine PC and PS induced sodium butyrate-mediated growth inhibition, differentiation and apoptosis in colon carcinoma Caco-2 cells ${ }^{28)}$.

The results of the current in vivo study provide the first evidence that oral administration of A. blazei extract directly or encapsulated liposomal form suppressed myeloma in mice. It has been reported that application of extracts from the medicinal mushrooms Phellinus igniarius and Agrocybe cylindracea could inhibit chemical carcinogen-induced skin cancers in mouse models by up to $88 \%{ }^{411}$. In addition, $\beta$-glucan of $A$. blazei inhibited growth of Meth A tumor in BALB/c mice ${ }^{42}$. Mushrooms of the higher Basidiomycetes origin showed activity against many experimental tumors, including sarcoma 180, mammary adenocarcinoma 755, leukemia L-1210, and HeLa cell lines ${ }^{43}$. Water extract of Phellinus rimosus inhibited growth of Dalton's lymphoma ascites in Swiss albino mice ${ }^{44)}$. And extract of Lepista inversa inhibited growth of leukemia and Lewis lung carcinoma in DBA/2 mice ${ }^{45}$. Moreover, oral administration of $\beta$-glucan reduced peritoneally disseminated metastasis in a mouse model using human ovarian cancer HRA cells and 3LL lung cancer in mice $^{46)}$. Furthermore, epidemiological studies from selected area in Japan and Brazil suggest that prolonged consumption of the medicinal mushrooms Flammulina velutipes and A. blazei were associated with lower overall rates of cancer mortality ${ }^{47}$. The oral administration of $A$. blazei extract and/or marine phospholipid had no effect on body weight gain in myeloma-bearing mice. Our findings suggest that the antitumor effect of $\beta$-glucan and/or marine phospholipid was demonstrated with the absence of side effects such as weight loss, which might indirectly affect cancer. The results obtained in this study suggest that though the suppression mechanism is still unclear, combined administration of $A$. blazei extract and marine phospholipid might be useful in myeloma sp2 therapy. 


\section{References}

1. Manzi, P.; Gambelli, L.; Marconi, S.; Vivanti, V.; Pizzoferrato, L. Nutrients in edible mushroom: An interspecies comparative study. Food Chem. 65, 477-482 (1999).

2. Chang, R. Functional properties of edible mushrooms. Nutr. Rev. 54, S91-S93 (1996).

3. Mattila, P.; Suonpaa, K.; Pironen, V. Functional property of edible mushrooms. Nutr. 16, 694-696 (2000).

4. Muchove, J.J.; Muchove, R.M.C. Nocoes Basicas de Microbiologia. Minas Gerais: Editira Folha de Vicisa (1989).

5. Smith, J.E. The magic of mushrooms. Functional Foods Sept./Oct. pp.18-21 (2000).

6. Mizuno, T.; Saito, H.; Nishitoba, T.; Kawaguchi, H. Antitumor-active substances from mushroom. Food Rev. Intr. 11, 23-61 (1995).

7. Wasser, S.P.; Weis, A.L. Therapeutic effects of substances occurring in higher basidiomycetes mushrooms: A modern perspective. Critical Rev. Immunol. 19, 65-96 (1999).

8. Asfors, K.E.; Ley, K. Sulfated polysaccharides in inflammation. J. Lab. Clin. Med. 121, 201-202 (1993).

9. Longvah, T.; Deosthale, Y.G. Compositional and nutritional studies on edible wild mushroom from northeast India. Food Chem. 63, 331-334 (1998).

10. Borchers, A.T.; Stern, J.S.; Hackman, R.M.; Keen, C.L.; Gershwin, M.E. Mushrooms, Tumors and Immunity. Proc. Soc. Exp. Biol. Med. 221, 281-293 (1999).

11. Beier, R.C. Natural pesticides and bioactive components in foods. Rev. Environ. Contam. Toxicol. 113, 47-137 (1990).

12. Mizuno, T.; Inagaki, R.; Kanno, T.; Hagiwara, T.; Nakamura, T.; Itoh, T.; himura, K.; Sumiya, T.; Asakura, A. Antitumor activity and some properties of water-soluble polysaccharides from "himematsutake", the fruiting body of Agaricus blazei Murill. Agric. Biol. Chem. 54, 2889-2896 (1990).

13. Fujimiya, Y.; Suzuki, Y.; Katakura, R.; Ebina, T. Tumorspecific cytocidal and immunopotentiating effects of relatively low molecular weight products derived from the basidiomycete, Agaricus blazei Murill. Anticancer Res. 19, 113-118 (1999).

14. Takaku, T.; Kimura, Y.; Okuda, H. Isolation of an antitumor compound from Agaricus blazei Murill and its mechanism of action. J. Nutr. 131, 1409-1413 (2001).

15. Fujimiya, Y.; Suzuki, Y.; Oshima, K.; Kobori, H.; Moriguchi, K.; Nakashima, H.; Matsumoto, Y.; Takahara, S.; Ebina, T.; Katakura, R. Selective tumoricidal effect of soluble proteoglucan extracted from the basidiomycete, Agaricus blazei murill, mediated via natural killer cell activation and apoptosis. Cancer Immunol. Immunother. 46, 147-159 (1998).

16. Lee, Y.L.; Kim, H.J.; Lee, M.S.; Kim, J.M.; Han, J.S.;
Hong, E.K.; Kwon, M.S.; Lee, M.J. Oral administration of Agaricus blazei (H1 strain) inhibited tumor growth in a sarcoma 180 inoculation model. Exp. Anim. 52, 371-375 (2003).

17. Wannet, W.J.B.; Hermans, J.H.M.; Drift, C.V.; Huub, J.M. HPLC detection of soluble carbohydrates involved in mannitol and trehalose metabolism in the edible mushroom Agaricus bisporus. J. Agric. Food Chem. 48, 287-2910 (2000).

18. Grosev, V.M.; Bozac, R.; Puppels, G.L. Vibrational spectroscopic characterization of wild growing mushroom and toadstools. Spectrochim. Acta (Part A) 57, 28152829 (2001).

19. Ito, H.; Shimura, K.; Itoh, H.; Kawade, M. Antitumor effects of a new polysaccharide-protein complex (ATOM) prepared from Agaricus blazei (Iwade Strain 101) "Himematsutake", and its metabolism in tumor bearing mice. Anticancer Res. 17, 277-284 (1997).

20. Shu, C.H.; WEN, B.J.; Lin, K.J. Monitoring the polysaccharide quality of Agaricus blazei in submerged culture by examining molecular weight distribution and TNF- $\alpha$ release capacity of macrophage cell line RAW 264.7. Biotechnol. Lett. 26, 2061-2064 (2004).

21. Dong, Q.; Yao, J.; Yang, X.T.; Fang, J.N. Structural characterization of water-soluble $\beta$-D-glucan from fruiting bodies of Agaricus blazei Murr. Carbohydr. Res. 337, 1417-1423 (2002).

22. Itoh, H.; Amano, H.; Noda, H. Inhibitory action of a (16)- $\beta$-D-glucan-protein complex (FIII-2b) isolated from Agaricus blazei murill ("Himematsutake") on meth a fibrosarcoma bearing mice and its antitumor mechanism. Jpn. J. Pharmacol. 66, 265-271 (1994).

23. Ebina, T.; Fujimiya, Y. Antitumor effect of a peptideglucan preparation extracted from Agaricus blazei in a double-grafted tumor system in mice. Biotherapy 11, 259-265 (1998).

24. Ito, Y.; Nakamura, Y. Suppression of aflatoxin B1 or methyl methanesulfonate-induced chromosome aberrations in rat bone marrow cells after treatment with Smethanethiosulfonate. Mutat. Res. 393, 307-316 (1997).

25. Ohno, N.; Furukawa, M.; Miura, N.; Adachi, Y.; Motoi, M.; Yadomae, T. Antitumor beta-glucan from the cultured fruit body of Agaricus blazei. Biol. Pharm. Bull. 24, 820-828 (2001).

26. Kodama, N.; Komuta, K.; Nanba, H. Can maitake MDfraction aid cancer patients? Altern. Med. Rev. 7, 236239 (2002).

27. Hrčkova, G.; Velebnȳ, S.; Daxnerová, Z.; Solár, P. Praziquantel and liposomized glucan-treatment modulated liver fibrogenesis and mastocytosis in mice infected with Mesocestoides vogae ( $M$. corti, Cestoda) tetrathyridia. Parasitology 132, 581-594 (2006).

28. Hossain, Z.; Konishi, M.; Hosokawa, M.; Takahashi, K. Effect of polyunsaturated fatty acid-enriched phos- 


\section{K. Murakawa, K. Fukunaga, M. Tanouchi et al.}

phatidylcholine and phosphatidylserine on butyrateinduced growth inhibition, differentiation and apoptosis in caco-2 cells. Cell Biochem. Funct. 24, 159-165 (2006).

29. Hosokawa, M.; Shimatani, T.; Kanada, T.; Inoue, Y.; Takahashi, K. Conversion to docosahexaenoic acidcontaining phosphatidylserine from squid skin lecithin by phospholipase D-mediated transphosphatidylation. J. Agric. Food Chem. 48, 4550-4554 (2000).

30. Lepage, G.; Roy, C.C. Direct transesterification of all classes of lipids in a one-step reaction. J. Lipid Res. 27, 114-120 (1986).

31. Takahashi, K.; Hirano, T.; Saito, M. Application of partition chromatographic theory for the analysis of marine triglyceride molecular species. Nippon Suisan Gakkaishi 54, 523-528 (1988).

32. Hossain, Z.; Kurihara, H.; Hosokawa, M.; Takahashi, K. Docosahexaenoic and eicosahexaenoic acids-enriched phosphatidylcholine liposomes enhance the permeability, transportation and uptake of phospholipids in Caco-2 cells. Mol. Cell. Biochem. 285, 155-163 (2006).

33. Hope, M.J.; Bally, M.B.; Webb, G.; Cullis, P.R. Production of large unilamellar vesicles by a rapid extrusion procedure. Characterization of size distribution, trapped volume and ability to maintain a membrane potential. Biochim. Biophys. Acta 812, 55-65 (1985).

34. Sorimachi, K.; Amimoto, K.; Ikehara, Y.; Inafuku, K.; Okubo, A.; Yamazaki, S. Secretion of TNF- $\alpha$, IL-8 and nitric oxide by macrophages activated with Agaricus blazei Murill fractions in vitro. Cell Struct. Funct. 26, 103-108 (2001).

35. Liu, F.; Ooi, V.E.C.; Chang, S.T. Free radical scavenging activities of mushroom polysaccharide extracts. Life Sci. 64, 1005-1011 (1999).

36. Pinheiro, F.; Faria, R.R.; Decamargo, J.L.V.; SinardiBarbisan, A.L.T.; Daeira, A.F.; Barbisan, L.F. Chemoprevention of preneoplastic liver foci by dietary mushroom Agaricus blazei Murill in the rat. Food Chem. Toxicol. 41, 1543-1550 (2003).

37. Alves de Lima, P.L.; Delmanto, R.D.; Sugui, M.M.; da Eira, A.F.; Salvadori, D.M.; SPEIT, G.; RIBEIRO, L.R. Letinula edodes (Berk.) pegler (Shiitake) modulates genotoxic and mutagenic effects induced by alkylating agents in vivo. Mutat. Res. 496, 23-32 (2001).

38. Sugui, M.M.; Alves de Lima, P.L.; Delmanto, R.D.; da Eira, A.F.; Salvadori, D.M.F.; Ribeiro, L.R. Antimutagenic effect of Lentinula edodes (Berk.) pegler mush- room and possible variation among lineages. Food Chem. Toxicol. 41, 555-560 (2003).

39. Soiffer, R.J.; Murray, C.; Shapiro, C.; Collins, C.; Chartier, S.; Lazo, S.; RITZ, J. Expansion and manipulation of natural killer cells in patients with metastatic cancer by low-dose continuous infusion and intermittent bolus administration of interleukin-2. Clin. Cancer Res. 2, 493-499 (1996).

40. Ahn, W.S.; Kim, D.J.; Chae, G.T.; Lee, J.M.; Bae, S.M.; Sin, J.I.; Kim, Y.W.; Namkoong, S.E.; Lee, I.P. Natural killer cell activity and quality of life were improved by consumption of a mushroom extract, Agaricus blazei Murill kyowa, in gynecological cancer patients undergoing chemotherapy. Int. J. Gynecol. Cancer 14, 589594 (2004).

41. Shon, Y.H.; Nam, K.S. Cancer chemoprevention inhibitory effect of soybeans fermented with basidiomycetes on 7,12 dimethylbenz[a] anthracene/12-Otetradecanoylphorbol-13-acetate-induced mouse skin carcinogenesis. Biotechnol. Lett. 24, 1005-1010 (2002).

42. Ohno, N.; Miura, N.N.; Nakajima, M.; Yadomae, T. Antitumor $1,3-\beta$-glucan from the cultured fruit body of Sparassis crispa. Biol. Pharm. Bull. 23, 866-872 (2000).

43. Wasser, S.P.; Weis, A.L. Medicinal properties of substances occurring in higher basidiomycetes mushrooms: Current perspectives (review). Int. J. Med. Mushrooms 1, 31-62 (1999).

44. Ajith, T.A.; Janardhanan, K.K. Cytotoxic and antitumor activities of a polypore macrofungus, Phellinus rimosus (Berk) pilat. J. Ethnopharm. 84, 157-162 (2003).

45. Bezivin, C.; Delcros, J.G.; Fortin, H.; Amoros, M.; Boustie, J. Toxicity and antitumor activity of a crude extract from Lepista inversa (Scop.: Fr.) pat. (Agaricomycetideae). Int. J. Med. Mushrooms 5, 25-30 (2003).

46. Kobayashi, H.; Yoshida, R.; Kanda, Y.; Fukuda, Y.; Yagyu, T.; Inagaki, K.; Kondo, T.; Kurita, N.; Suzuki, M.; Kanayama, N.; Terao, T. Suppressing effects of daily oral supplementation of beta-glucan extracted from Agaricus blazei murill on spontaneous and peritoneal disseminated metastasis in mousemModel. $J$. Cancer Res. Oncol. 131, 527-538 (2005).

47. Ikekawa, T. Beneficial effects of edible and medicinal mushrooms on health care. Int. J. Med. Mushrooms 3, 291-298 (2001). 